\title{
THE EVOLUTION OF LATE MEDIEVAL SEIGNIORIAL RESIDENCES IN THE BASQUE COUNTRY. ANALYSIS OF THE GUEVARA PALACE AND ITS CONSTRUCTIVE SYSTEM
}

\author{
D. LUENGAS-CARREÑO, M. CRESPO DE ANTONIO \& S. SANCHEZ-BEITIA \\ Higher Technical School of Architecture, UPV/EHU.
}

\begin{abstract}
In the Late Middle Ages, the architectural form of Seigniorial Residences evolved from the defensive Tower Houses of the 14th and 15th centuries to the early Palaces of the 16th century, due to the decrease of the medieval conflicts. The analysis carried out in a previous project, which has generated an inventory of Late-Medieval Seigniorial Residences in the Basque Country, has identified four main evolutionary phases of this architectonic typology: Tower House, Tower House transformed into Palace, Tower House with annexed Palace and Pre-Renaissance Palace. This paper aims to analyze the constructive system of the last evolutionary phase, by the study of a characteristic Pre-Renaissance Palace: The Guevara Palace in Segura (Gipuzkoa-Spain). The building has been investigated through historical-documentary analysis and historical-constructive analysis, in order to determinate its original shape and constructive system. This research has identified six different building periods in the Guevara Palace. In spite of the building was significantly transformed in the 19th century, the study has determined that a significant number of original architectural elements have been kept, such as main façade sandstone masonry walls, a major part of the timber structure, Catholic Kings Style ornamentation details or several windows and doorways, some of them bricked up and covered. The information obtained has served to carry out the $3 \mathrm{D}$ reconstruction of the palace, showing the characteristic features of Pre-Renaissance Palaces. This paper is part of a broader research project which aims to develop a cataloguing model for Late-Medieval Seigniorial Residences of the Basque Country.

Keywords: heritage masonry buildings, historical-constructive analysis, late-medieval palaces, seigniorial residences.
\end{abstract}

\section{INTRODUCTION}

The Guevara Palace is placed in the royal foundation village of Segura, in the north of Spain. The palace was built in an important geostrategic point of the village: in the centre of the main street and next to one of the village gates. This representative case of Pre-Renaissance Palace covers a surface area of $395 \mathrm{~m}^{2}$, equivalent to three medieval plots of the town. Currently, the building has two floors. Taking advantage of the uneven ground, the northern part of the building has a mezzanine and a basement.

The main façade, which was built with sandstone masonry pieces, preserves some Catholic Kings Style elements, such as ogee windows, shields without mantling, gargoyles or lines of stone 'balls'. A large round arched doorway highlights above the rest of the architectonic elements, which was erected as the main entrance. The rear façade was built with poor masonry, without significant architectural elements. Nowadays, the palace is divided into three different properties, which has hindered to maintain and preserve the palace homogeneously.

\section{HISTORICAL CONTEXT}

The Seigniorial Residences were the homes and headquarters of the Basque lordly families in the Late Medieval Age. In the 13th century, the rural nobility was organized into pyramid-type structure lineages, which were leaded by the lineage chiefs, also known as 
'The Elders'. In the 14th century, the late medieval economic crisis and the rise of the royal foundation villages caused the decrease of the economic incomes of the rural nobility, and gave rise to several armed conflicts between neighboring lineages. Gradually, these struggles escalated into an open warfare between two partialities: the Gamboa faction and the Oñaz faction [1]. For this reason, as in other parts of Europe [2,3], The Elders began to build defensive residences: The Tower Houses. These parallelepiped masonry buildings were the first evolutionary phase of Late Medieval Seigniorial Residence typology and they resulted to be a very effective building typology to control the geostrategic points of the territory, such as bridges, roads, village gates or seaports. Although each Tower House controlled a small area, family alliances and the interconnection between these fortifications allowed the control of almost all medieval trade routes of the Basque Country (Fig. 1). Furthermore, the Tower Houses became lineage's administration centre and it served to articulate the clan's productive industries (mills, foundries, chapels, forests, iron mines...) [4].

The bloodiest period of the war between Gamboa and the Oñaz factions was in mid-15th century, when the fighting reached several royal foundation villages, such as Mondragon, which was burnt in 1448. As a result of this escalation of violence, the Castilian King Enrique IV decided to punish The Elders, demolishing their Tower Houses and prohibiting the construction of new military buildings [5]. Gradually, the intensity of the war was decreasing and the situation was pacified.

Under those circumstances, the Seigniorial Residences had to evolve to 'more domestic' forms in the late 15th century [6]. A significant number of lineages restored their Tower Houses into Palaces, reducing the height and opening new big size windows and doorways,

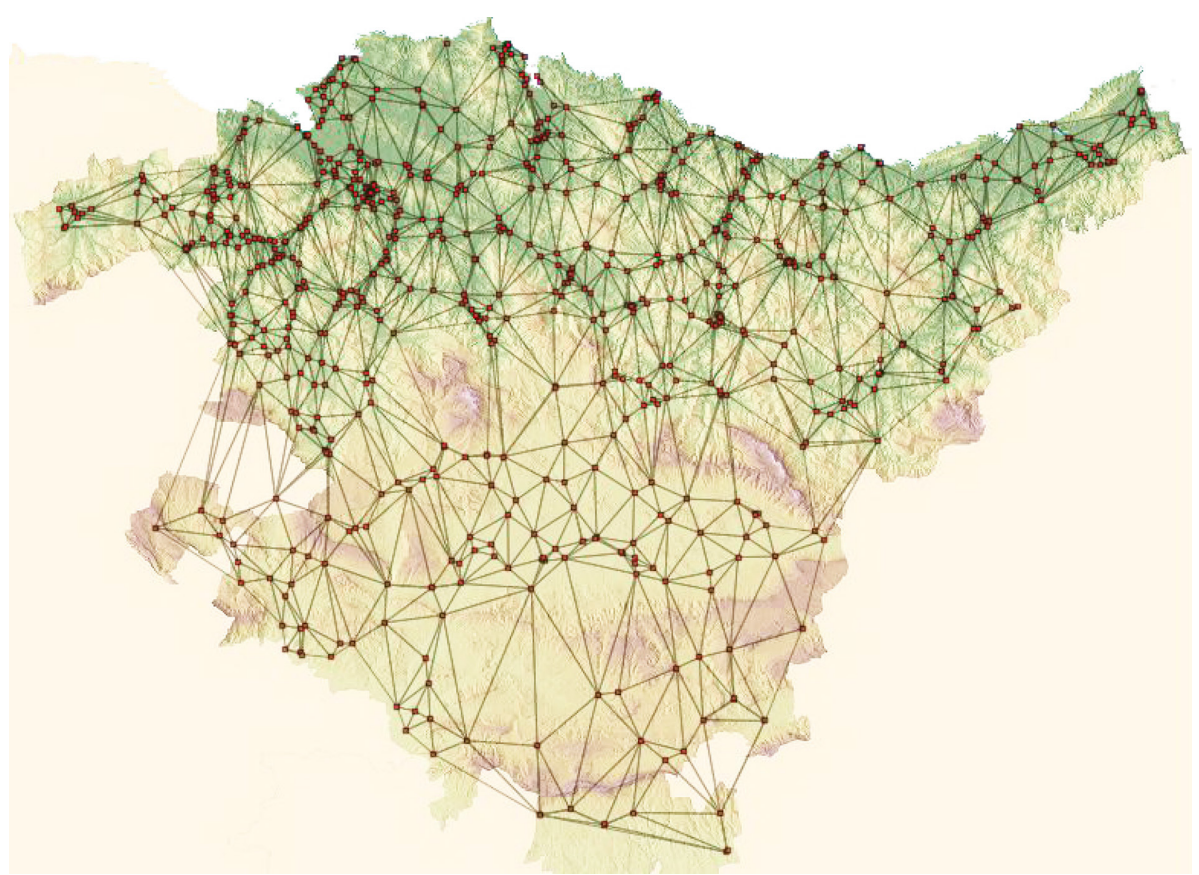

Figure 1: The tower houses system of the Basque Country. 


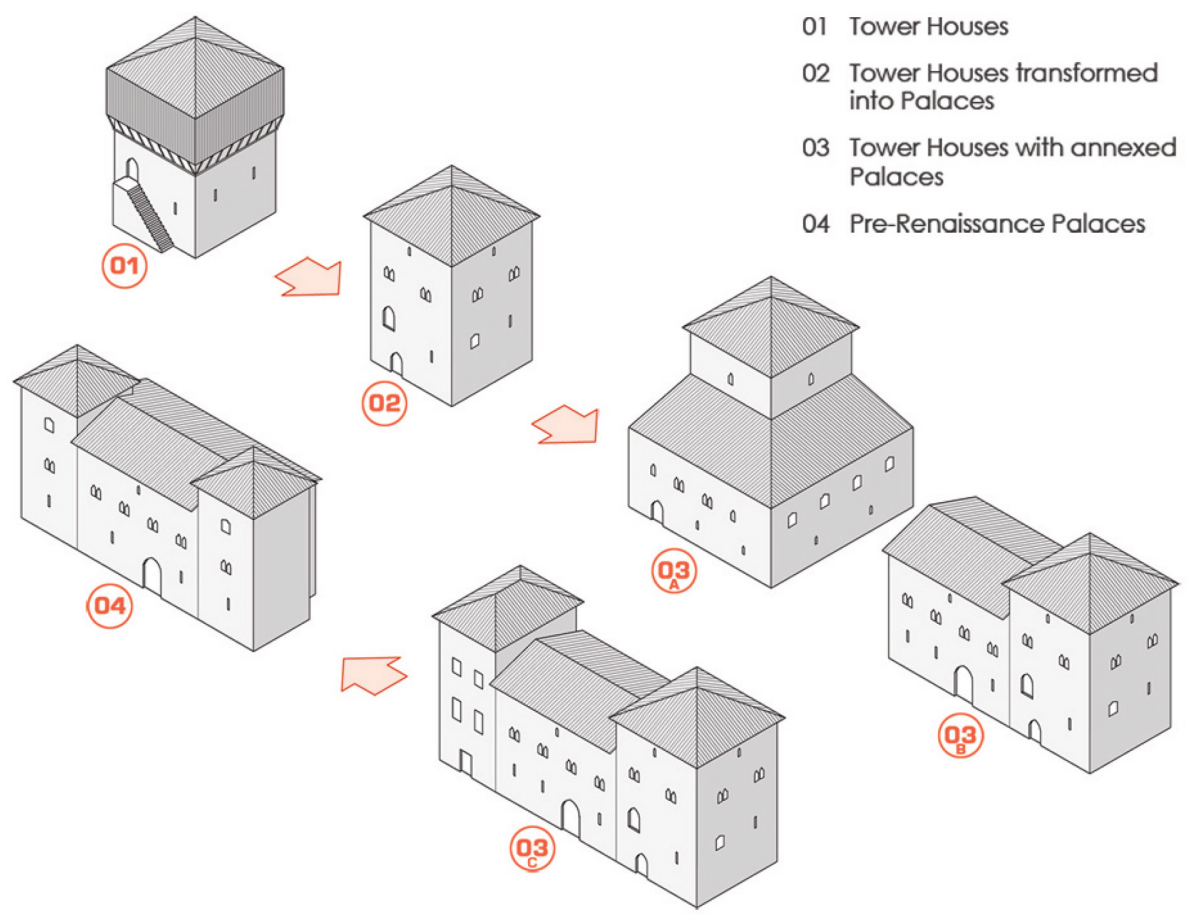

Figure 2: The evolution of Late-medieval Seigniorial Residences in the Basque Country.

with Catholic Kings Style ornamentation details, such as ogee heads, columns or stone figures representing animals, vegetation or spherical objects.

By contrast, other nobles preferred to build annexed Palaces to their Tower Houses, preserving the original construction (Fig. 2). These new residential spaces were more luminous and better equipped than previous ones. The annexed Palaces could be disposed parallel to the main façade or they could be built around the tower, sometimes using original perimeter stone fence walls.

This trend soon gave way to a new residential model: The Pre-Renaissance Palace of the early sixteenth, the last evolutionary phase of Late Medieval Seigniorial Residence typology. In spite of this palaces were not built with military function, they were designed and raised with the similar shape of the primitive Tower Houses, since they still were regarded as a symbol of nobility and high social status. In this regard, the Pre-Renaissance Palaces were raised using the same materials as previous evolutionary phases, but with more worked timber and stone elements. Moreover, these constructions were decorated using defensive architectonic elements, such as well worked arrowslits, ornamental towers or battlements. In this sense, as mentioned in a previous paper [7], the Guevara Palace is one of the most representative case studies of Pre-Renaissance Palace of the Basque Country.

\section{METHODOLOGY}

The building has been investigated through historical-documentary analysis and historicalconstructive analysis, in order to determine its original shape and constructive system. 
In the historical-documentary analysis, the documents were searched in the following archives: the Municipal Archive of Segura, the Historical Provincial Archive of Gipuzkoa, the Historical Protocol Archive of Gipuzkoa, the General Archive of Gipuzkoa, the Archive of the Royal Chancellery of Valladolid, the Historical State Archive of Spain and the General Archive of Simancas. Historical pictures, maps and photographs were obtained in the following digital repositories: the Digital repository of the Gipuzkoa Council, the Basque Digital Library, GureGipuzkoa repository, the Digital Periodical Library and EMD repository. The texts were edited using guidelines of the International Commission of Diplomatic [8].

In the historical-constructive analysis, the stratigraphic study of the façades was carried out using the Harris method [9]. This method is based on the creation of different temporal sequences, which are organized through a diagram called Harris Matrix. The matrix reflects the relative position and contacts of each observable stratigraphic unit. Complementarily, a detailed study of the walls was performed indicating different materials, building periods and alterations, such as not original walls or walled windows and doorways. A PCE-TC 3 thermal imaging camera was used to detect hidden items.

The information obtained in these two studies have been used to determinate the original shape and constructive system of the Guevara Palace. The 3D reconstruction was carried out with AutoCAD software. The final digital images were improved in Adobe PhotoShop.

\section{HISTORICAL-DOCUMENTARY ANALYSIS}

More than 50 historical documents were discovered during the research, most of them in the Municipal Archive of Segura, where architectural drawings of 1880 were located. The oldest picture of the palace dates from 1915, and it was discovered in the General Archive of Gipuzkoa. The analysis of historical documentation revealed six main building periods.

\subsection{Period 1 (1498-1613): Construction of the Palace}

The Guevara Palace was firstly historically mentioned in the testament of Nicolas de Guevara in 1504. Nicolas, the first owner on record of the palace, started the construction inthe late 15 th century, probably after the fire of 1492, which destroyed almost all constructions of Segura. According the testament of 1504, the Guevara Palace was built using stones of the destroyed Tower House of Bachiller Larrastegui, the brother of Nicolas.

Juan de Guevara, the successor of Nicolas, finished the construction in the early sixteenth century. In accordance with his testament of 1543, Juan built mezzanines, spiral staircase and fireplaces. The most notable document of this period is the confirmation of entailed estate of Diego de Guevara (the son of Juan), dated in 1573. Referring to a brief description of the Guevara Palace given in the document, the building originally had two side towers.

\subsection{Period 2 (1613-1853): Abandonment of the Palace}

In consonance with the documents of this period, Mariana Bonifaz Ladrón de Cegama, the owner of the Guevara Palace in the early 17 th, abandoned the palace and moved to Madrid in 1613. In the next decades, the building was leased to families with fewer economic resources, causing the deterioration of the architectural elements, due to the lack of proper maintenance. In this sense, documents of Municipal Archive of Segura revealed that the edifice was used as a hostel in the 18th and 19th centuries. 
According to a text of 1815 , the palace was in an advanced state of deterioration in the early nineteenth century. As a result, there was a collapse of one of its walls. Another document of the Archive of Segura of 1829 notes that the two side towers had serious damages and they were a risk for pedestrians.

\subsection{Period 3 (1853-1888): Removal of the top floor of the two side towers}

On April of 1853, the town council decided to demolish the top of the towers, because they were at risk of collapse. One year later, the palace was bought by Ignacio Martin Diez. Furthermore, in the next decades, it was rented by different families, which certainly opened new voids in the façades, in order to adapt the rooms to their needs. Lease documents also suggest that the palace lost surface area in the southern part in that period, where a new construction was raised.

\subsection{Period 4 (1888-1915): Subdivision into three different properties}

On May 6 of 1888, the Guevara Palace was purchased by Esteban Zurbano, who subdivided it into three different lots. In the subdivision works, new walls were raised and some elements were bricked up, as evidenced by the architectural drawings of 1888 (Fig. 3).

Another important document of this period is a photograph of 1915, obtained in the General Archive of Gipuzkoa, Fig. 3. Taking into consideration the differences between this image and the architectural drawings of 1888 , main façade was substantially transformed in this period.

\subsection{Period 5 (1915-1984): Some interior works}

On July 17 of 1984, the Guevara Palace was declared Historic Artistic Monument by the Basque Government. For this reason, government technicians carried out an inspection of the building, achieving an extensive photo report of the property. In consonance with these pictures, new voids were opened in the three façades in these decades. Furthermore, all
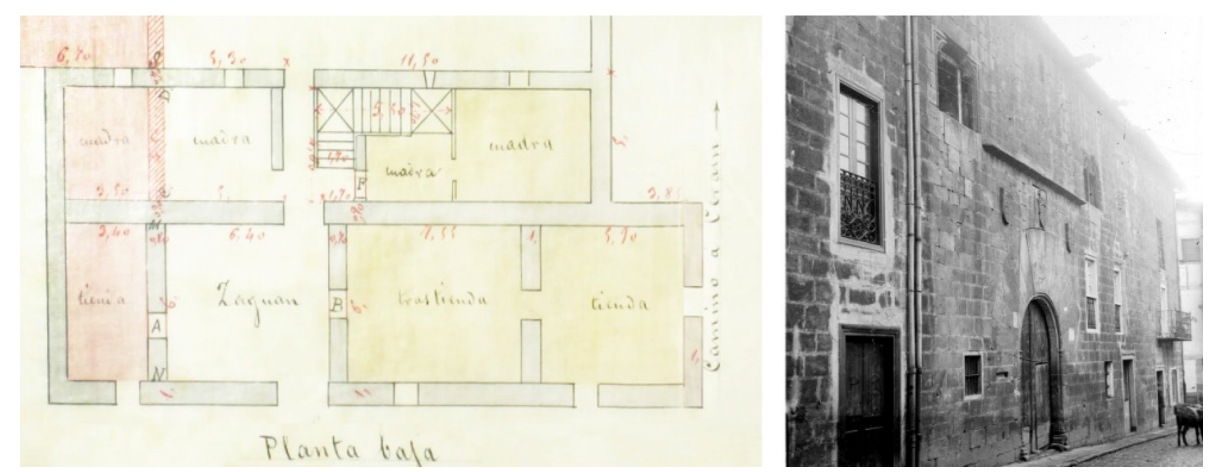

Figure 3: The photograph of 1915 and the subdivision drawings of 1888, where the southern part is painted in red, the central part appears in white and the northern part is in yellow. 
subdivisions of the palace were refurbished internally for 1984, since the photographs of this year show an almost identical interior decoration and distribution to the current one.

\subsection{Period 6 (1984-2014): Refurbishment of the central subdivision}

In accordance with a demolition project, the southern part of the building belonged to the adjoining property in 1987. This explains why this subdivision has different floor to floor heights in relation to the rest of the building.

The central subdivision of the palace was refurbished in 1994, thanks to a financial aid of the Provincial council of Gipuzkoa. The timber structure was strengthened, the central roof was replaced and two trefoiled windows were repaired. The last architectural intervention was made in 2008, when the rear garden was renovated and some annexed constructions were demolished.

\section{HISTORICAL-CONSTRUCTIVE ANALYSIS}

The information and building periods obtained in the previous historical-documentary analysis were used to guide the historical-constructive analysis.

\subsection{Period 1 (1498-1613): Construction of the Palace}

The original main walls were made in sandstone ashlars, which are distinguished by their great thickness and bounding, Fig. 4. The original walls have discontinuities in the southern part of the building and some of interior rooms conserve their original round arched doorways.

Thermal imaging camera revealed the bounding of a significant number of plaster covered walls and architectural elements. The research discovered an ogee-headed arrowslit in the ground floor (Fig. 4, stratigraphic unit 36), remains of three double trefoiled windows in the main floor (Fig. 4, units 24 and 37), a small ogee-headed window at the top of the main façade (Fig. 4, unit 29) and four round arched doors in the rooms, Fig. 5.

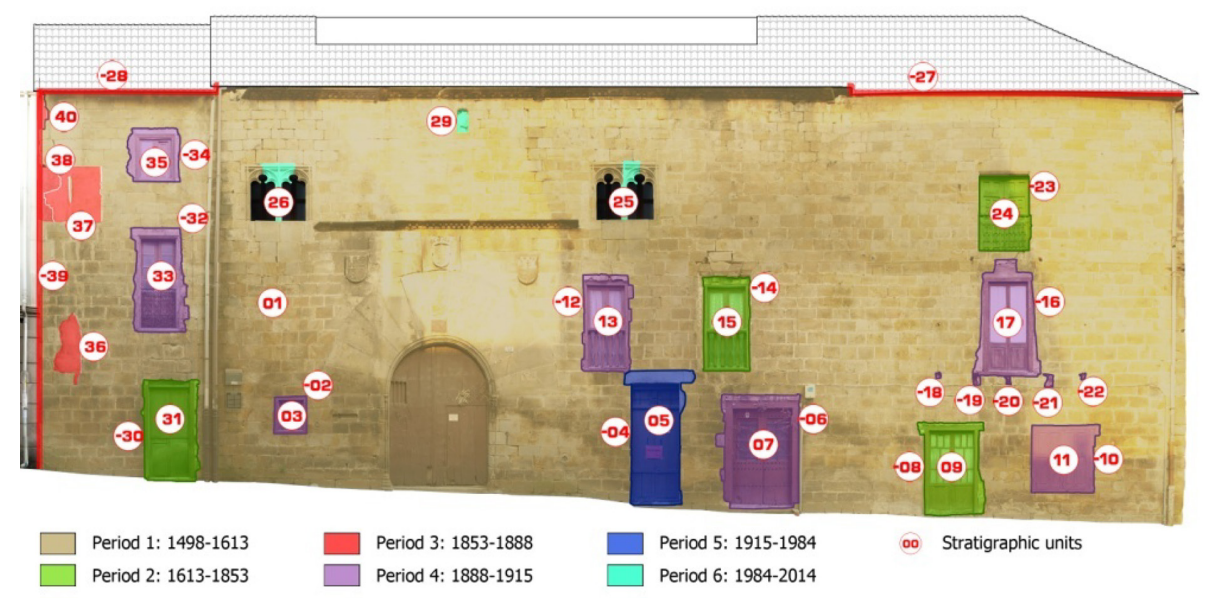

Figure 4: Stratigraphic study of the main façade. 


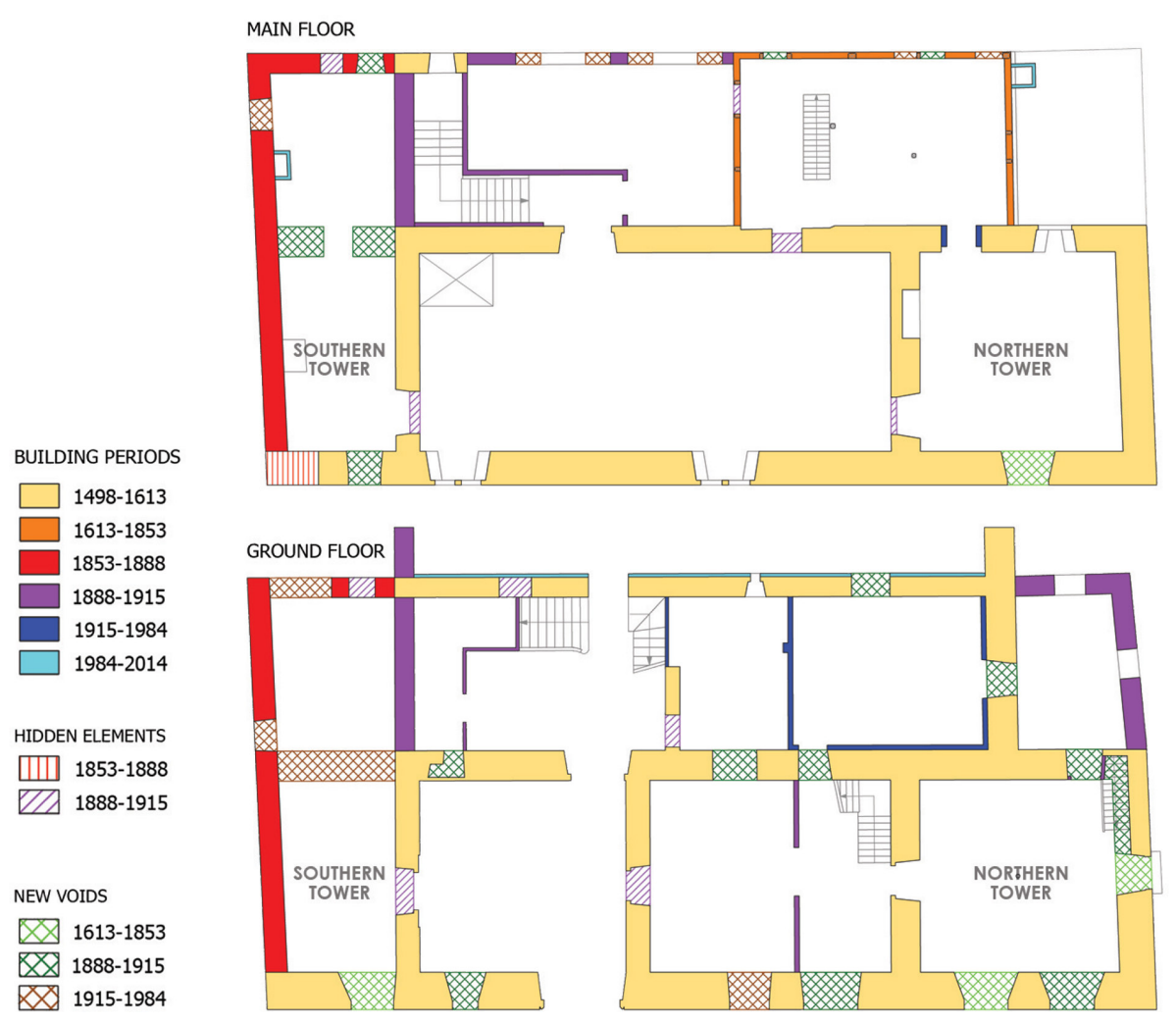

Figure 5: Building periods of the main and ground floor.

\subsection{Period 2 (1613-1853): Abandonment of the Palace}

As mentioned in the previous studies, the Guevara family abandoned the palace in the early sixteenth, and it was rented to peasant families, who used it as an inn. The renters erected new walls, built more rooms both in the mezzanine and in the main floor (right side of Fig. 5) and opened new windows in the main façade (Fig. 4, units 9, 15, 24 and 31). In addition, a timber framing enclosure was raised in the northern part of the rear façade, which replaced a previous one destroyed in a fire, as evidenced by remains found in the adjacent walls.

\subsection{Period 3 (1853-1888): Removal of the top floor of the two side towers}

The most relevant remains of this period are the cuts produced by the demolition of the side towers (Fig. 4, units 39, 27 and 28). During this refurbishing work, a double trefoiled window and an ogee-headed arrowslit were bricked up (Fig. 4, units 36 and 37). In the southern part, a new poor masonry rear façade and dividing wall were built, Fig. 5.

\subsection{Period 4 (1888-1915): Subdivision into three different properties}

According to the architectural drawings of 1888, the most important transformation was carried out in this period. During this refurbishing, an annexed construction was built and a 


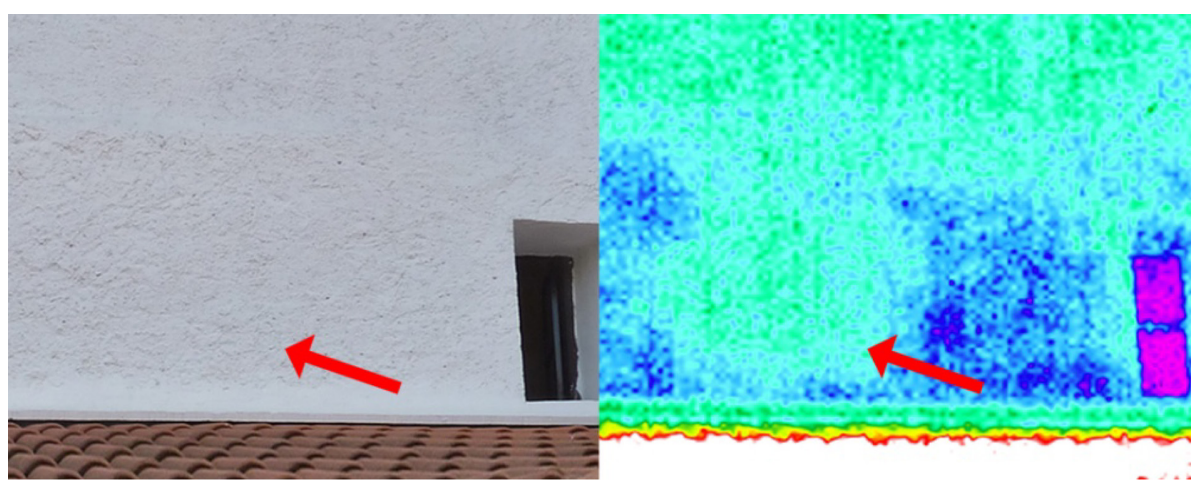

Figure 6: Hidden window in the rear façade.

basement was excavated in the northern part. A new masonry wall was also raised between the southern and central subdivisions and a timber framing enclosure was erected in the central part of the rear façade, Fig. 5. In this period, 14 new façade voids were opened, seven new inside passages were built and eight voids were bricked up.

The thermal imaging camera revealed a significant number of hidden architectural elements, such as rear façade windows (Fig. 6), which appear in the drawings of 1888 . Additionally, this camera was used to distinguish between the paste covered original and not original walls, owing to the difference of emissivity of the materials of both types of walls.

\subsection{Period 5 (1915-1984): Some interior works}

In this building period few changes were made. Three new brick walls were raised in the back areain order to build a new kitchen. In the southern subdivision, a masonry inner wall was demolished, some windows were bricked up and new voids were opened in the dividing wall, Fig. 5.

\subsection{Period 6 (1984-2014): Refurbishment of the central subdivision}

During the refurbishment of the central subdivision, some brick walls were erected in order to create new rooms, Fig. 5. Additionally, two double trefoiled windows and a small ogeeheaded window were repaired (Fig. 4, units 25, 26 and 29).

\section{ORIGINAL SHAPE AND CONSTRUCTIVE SYSTEM OF THE PALACE}

Taking into consideration the information obtained in the historical-documentary analysis and the historical-constructive analysis, the original building had two side towers. The northern tower has conserved the original masonry walls, both in the first and the second floor. By contrast, the southern tower, whose structure has been altered enormously, only has retained a part of the main façade and the northern wall. In the ground floor, the main façade of the northern tower is $1.15 \mathrm{~m}$ thick, the side façade is $1.1 \mathrm{~m}$ thick, the back façade is $0.93 \mathrm{~m}$ thick and the southern wall is $0.9 \mathrm{~m}$ thick. In the main floor, the walls are approximately $0.1 \mathrm{~m}$ thinner, except the southern wall, which has the same thickness in both floors. Due to this difference in thickness, the wooden structure can rest directly on the projecting part of the 
stonework. Furthermore, the northern tower has preserved the lower stone rows of the removed top floor, which are approximately $0.6 \mathrm{~m}$ thick.

In comparison with a previous research work [6], the side towers of the Guevara Palace are substantially thinner (52\%) than previous evolutionary phases of Late-medieval Seigniorial Residence typology. For example, the primitive Tower House is normally about $1.5-1.8 \mathrm{~m}$ thick in the ground floor, 1.25-1.6 $\mathrm{m}$ in the main floor and 1.1-1.4 $\mathrm{m}$ in the top floor. Probably, the structural damages documented in the 19th century were caused by this lack of thickness.

According to the preserved remains and the information obtained in the archives, the ground floor was mainly used as a stable and warehouse. The kitchen and the rooms of the servants were located in the mezzanine floor. On the contrary, the main floor accommodated the most relevant rooms of the house. Thus, the main hall, the most important space of the palace, was in the central part, between the two side towers. In the rear façade was the "solana" or sunny side room, as evidenced by the remains discovered by the thermal imaging camera. Finally, in the two side towers were the bedrooms of the lords, which were the most private spaces of the Guevara Palace.

In the top of the main façade a horizontal stone-carved conduit was found, which served to channel the rainwater to five gargoyles. Therefore, the original roof had a double water gutter, as it is shown in the Fig. 7. Taking into account other best-preserved Pre-Renaissance Palaces [6], the roof of the side towers should have been built with similar structure, but there is no evidence.

As mentioned above, the original main walls of the Guevara Palace were made with sandstone ashlars. Unlike the primitive Tower Houses, the façades of the Pre-Renaissance Palaces were hierarchically structured. In this sense, the main façade has the best stone work and

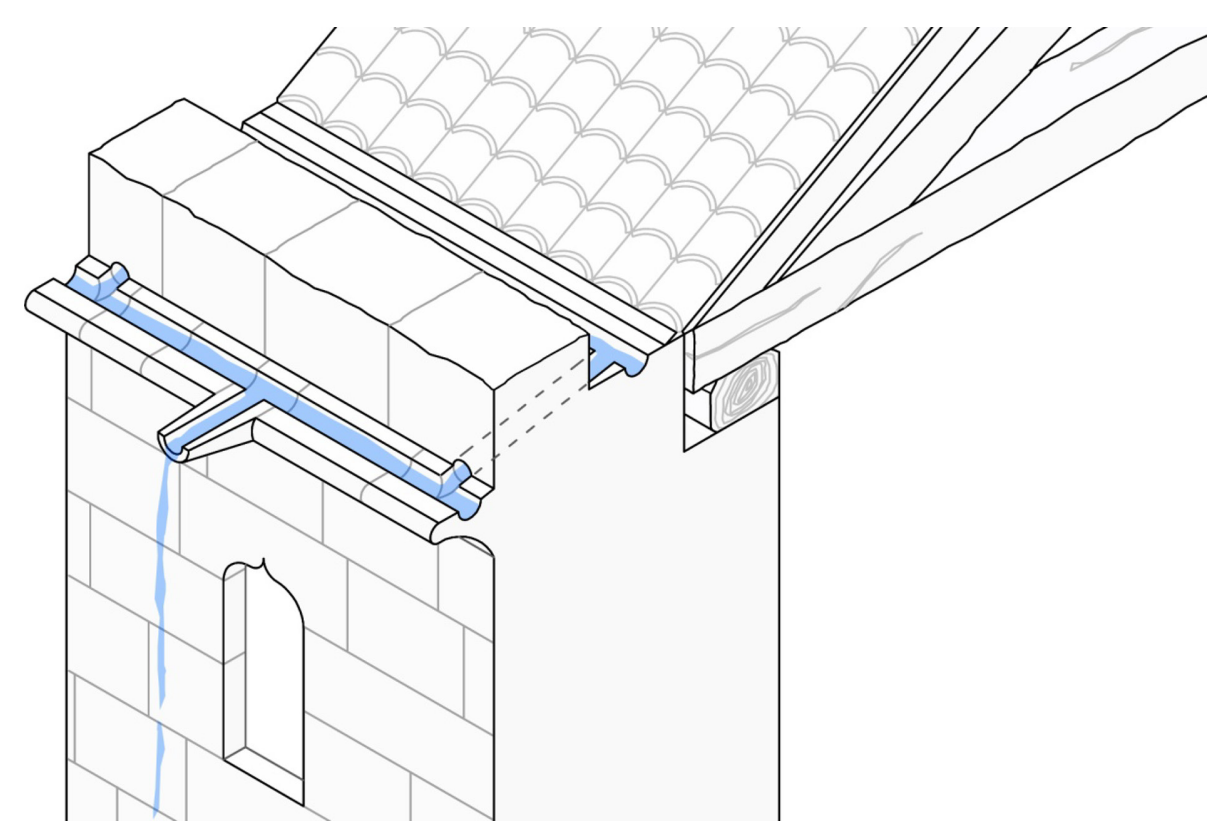

Figure 7: The original roof and the stone-carved rainwater conduit. 
Catholic Kings Style ornamentation, such as lines of stone 'balls', gargoyles or stone canopies.

The original Guevara Palace had few windows and doors (Fig.8), which were simply organized. The main façade had a single entry: the large round arched doorway. This architectural element, which was formed by thirteen voussoirs of $1.6 \mathrm{~m}$ in length, was $3.33 \mathrm{~m}$ high and $2.32 \mathrm{~m}$ wide. This door gap size made possible to enter on horseback inside the palace. The doorway was ornamented with two side renaissance columns and three gothic shields. Nevertheless, there are no architectural remains, according to the historical documents; the rear façade had a doorway in the ground floor.

In the ground floor, the building retains a single original window: an ogee-headed arrowslit, which was placed in the southern tower. Remains found in the interior side of the wall revealed the possible existence of another ogee-headed arrowslit in the northern tower (Fig. 4, unit 09). In this sense, the mezzanine have preserved remains of two original windows (Fig. 4, units 15 and 17), which were bigger than ground floor windows, but whose shape is unknown.

The most relevant windows of the Guevara Palace were in the main floor. The main façade have conserved a gallery of four double trefoiled windows (Fig. 4, units 24, 25, 26 and 37), with stone side benches. Moreover, remains of a fifth double trefoiled window were found in the rear façade of the northern tower. Finally, a bricked-up small ogee-headed window was discovered on the top of the centre of the facade. Taking into account other Pre-Renaissance Palaces, such as the Lili Palace in Zestoa, the removed top floor of the towers should not have had many windows. It is likely they were ogee-headed windows, as mentioned above.

2015

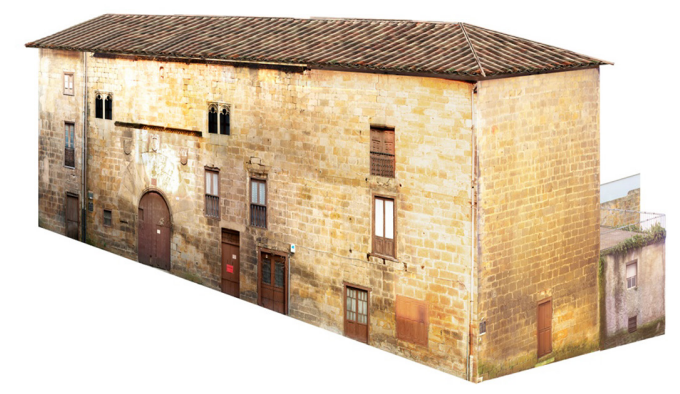

1543

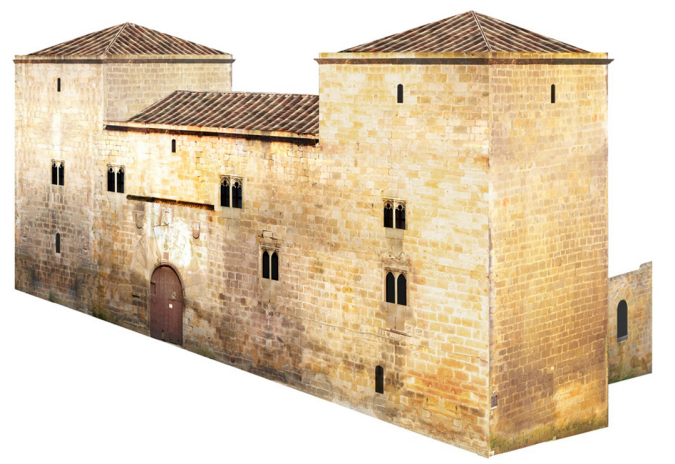

Figure 8: 3D reconstruction of the palace. 


\section{MEZZANINE FLOOR}

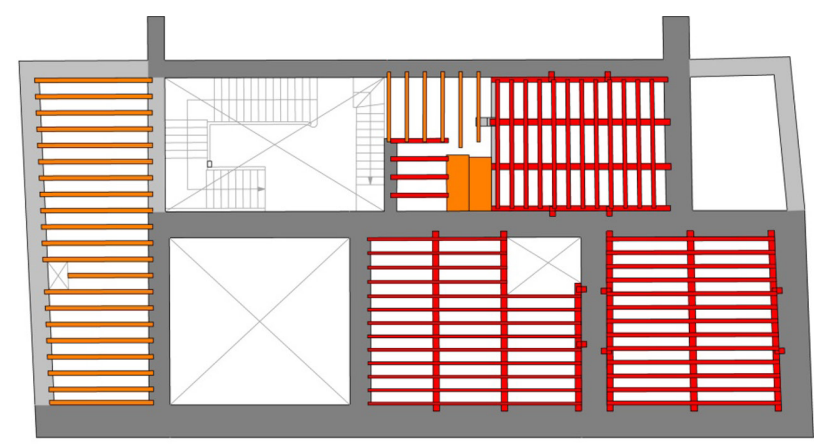

MAIN
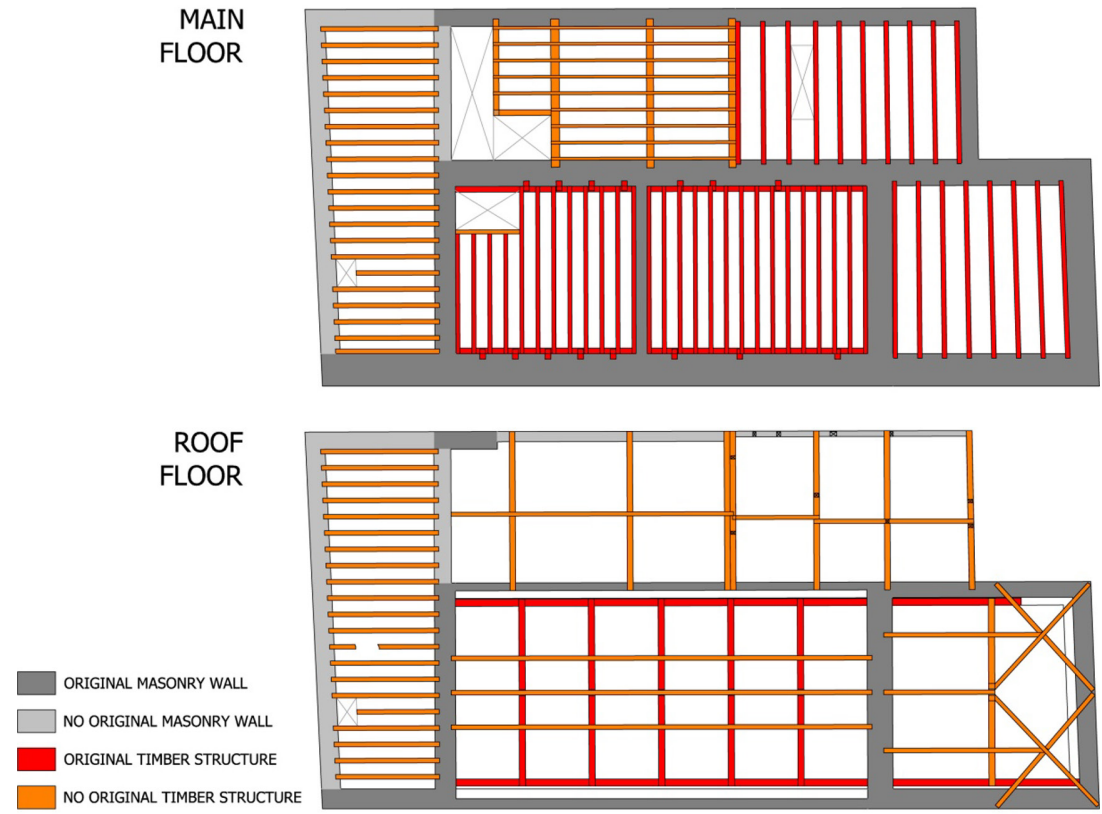

Figure 9: Original timber and masonry elements.

Moreover, the building has preserved a significant number of oak timber structural elements, as it is shown in Fig. 8. In the mezzanine floor, the side timber beams were held up by stone brackets and the central beams were embedded into the walls. In the north part of the first floor, the structure rested directly on the projecting part of the stonework. However, in the central part, the structure was supported by two timber sleepers, which were supported by stone brackets. The central roof was held up by five king post trusses. No original timber elements were found in the south part.

\section{CONCLUSION}

This paper is a contribution toward understanding the architectural form of Late-medieval Seigniorial Residences in the Basque Country, through the study of a characteristic edifice of the last evolutionary phase of this building-typology: the Pre-Renaissance Palace. 
The methodology was appropriate to determine the original shape and constructive system of the Guevara Palace. The historical-documentary analysis was useful to understand the alterations of the Guevara Palace over its history, produced by the changes in use and a subdivision process. In this sense, the study found six main building periods, which served to structure the historical-constructive analysis.

The historical-constructive analysis was helpful to determine the architectural original elements and to define a formal image of the primitive construction: a large round arched doorway, some arrowslit form windows discovered in the ground floor and a gallery of five trefoiled windows of two lights in the main hall (the research discovered three of them). Moreover, the thermal imaging camera was a useful tool to reveal a significant number of hidden architectural elements.

The study is part of a broader research project which aims to develop a cataloguing model for Late-Medieval Seigniorial Residences of the Basque Country. Further research is needed to determine the evolution of the construction system of this building-typology, by the study of other characteristic buildings of the four main evolutionary phases (single Tower House, Tower House transformed into Palace, Tower House with annexed Palace and Pre-Renaissance Palace).

\section{ACKNOWLEDGEMENT}

This paper was supported by a research training grant from the Research Vicerrectorate of the University of the Basque Country UPV/EHU. The researchers also want to acknowledge the assistance provided by the staff and researchers of the Higher Technical School of Architecture of San Sebastian, especially to Arritokieta Eizaguirre and Irati Otamendi.

\section{REFERENCES}

[1] González, C.J.M., Torres de las Encartaciones, Diput. Foral de Bizkaia: Bilbao, 2004.

[2] Sherlock, R., Cross-cultural occurrences of mutations in tower house architecture: evidence for cultural homogeneity in Late Medieval Ireland? The Journal of Irish Archaeology, 15, pp. 73-91, 2006.

[3] Cruden, S., The Scottish Castle, Nelson: Edinburgh, 1960.

[4] Portilla, V.M.J., Torres y casas fuertes en Alava, Caja Ahorros Municipal: Vitoria, 1978.

[5] Bazán, DI., El refugio de la delincuencia señorial. Torres y casas fuertes en el País Vasco: el ejemplo de la Torre de Berna. Sancho el sabio: Revista de cultura e investigación vasca, 8, pp. 23-50, 1998.

[6] Luengas-Carreño, D. \& Sanchez-Beitia, S., Late-medieval Seigniorial Residences in the Basque Country: analysis of the evolution of construction system and its singular elements. Proceeding of the Rehabend 2014, Universidad de Cantabria: Santander, pp. 110-117, 2014.

[7] Luengas-Carreño, D., Crespo de Antonio, M. \& Sanchez-Beitia, S., The evolution of late medieval seigniorial residences in the Basque Country: analysis of a pre-renaissance palace: the Guevara Palace in Segura (Gipuzkoa, Spain). WIT Transactions on the Built Environment, 153, 2015, ISSN 1743-3509

[8] International Commission of Diplomatic, Folia Caesaraugustana I, Fernando el Católico Institution: Zaragoza, 1984.

[9] Harris, E.C., Principles of Archaeological Stratigraphy, Elsevier: London \& New York, 1989. 